\title{
Impact of Microfinance on Entrepreneurs in Afghanistan: An Analysis of Selected Cases
}

\author{
Chandrashekhar.R. ${ }^{1}$, Azizuddin Sultani ${ }^{2}$ \\ ${ }^{1}$ Assistant Professor, ${ }^{2}$ Ph.D. Research Scholar, \\ 1, 2 Department of Business Administration, Mangalore University, Dakshina Kannada, Karnataka, India
}

\begin{abstract}
Microfinance and entrepreneurship help decrease poverty and leads to economic growth in the least developed countries (LDCs). Generally, entrepreneurs in Afghanistan are underprivileged due to the lack of financial and infrastructure resources and uncertain political situations to operate their businesses. In the last decades, Afghan entrepreneurs set up their small and micro businesses with government and microfinance institutions' financial support. This research considered 28 entrepreneurs' success stories to examine how microfinance impacts their income growth after receiving loans. The study is constructed on the secondary data source, and the statistical analysis was conducted using IBM SPSS 25. Therefore, the data was not normally distributed. The authors used the Wilcoxon Sing Rank Test, a Nonparametric Test, and found that microfinance positively impacts an entrepreneur's income in Afghanistan. The research also indicated that there had been a significant improvement in saving level and employment opportunities since they have availed loans from MFIs/MFB. The finding of this case study, coupled with the MFIs/MFB, claims that MFIs/MFB improve the entrepreneur's income, savings and facilitate employment opportunities.
\end{abstract}

Keywords: Afghanistan, Empowerment, Entrepreneurship, Income Generation, Microfinance

\section{INTRODUCTION}

Microfinance means providing financial services to self-employed rural and urban poor. Loan, insurance, and technical support are typically included for low-income customers' financial services [1]; [2]. Since its modern growth in Bangladesh in the 1970s, microfinance has been widely praised as the solution to extreme deprivation [3]. Microfinance intends to provide those vulnerable with loans, deposits, and other financial services because they cannot provide appropriate collateral or have convenient access to banks. Microfinance will thus provide limited capital for the start-up and expansion of small businesses, especially for people with low incomes and households in the developing world.

Muhammad Yunus, an economist in rural Bangladesh in the 1970s, became dissatisfied with the reactions to frequent droughts in Bangladesh. He planned to enter small towns, where he found 42 women who made stools of bamboo. They were locked into a debt loop with local traders since they needed funds to buy raw materials, who loaned money for materials to promise that they would sell the stools at a price better than the cost of the raw materials. Muhammad Yunus was shocked, noticing that these 42 women's borrowers required a sum of 27 U.S. Dollar; the women were selling their goods at a higher price by lending them money from their pocket at no interest and thus broke out the debt loop. The solution appeared clear, and the critical issue was money. In other words, it was offering poor access to capital in the form of small loans that can be utilized to expand small businesses, allowing them to increase their standard of living in turn [4].

With indebted government financial organizations and no personal funds, Afghan's official financial system was nearly not operating till the end of 2001. Therefore, dependence on unofficial financing outlets such as relatives and colleagues, money changers, shopkeepers, and dealers. Besides, there was restriction coverage of microfinance services in the country.

The World Bank and the new Afghan government members joined forces to establish a single mechanism for channeling what was hoped would be significant investments in the new, rapid-growth microfinance industry. The Microfinance Investment Support Facility for Afghanistan (MISFA) was built as an apex institution in 2003, and the World Bank's Afghanistan Reconstruction Trust Fund (ARTF) was supported financially. Consultative Group to Assist the Poor (CGAP) was brought on the panel to deliver microfinance technical knowledge. This system has helped organize donor funding, encourage international and local NGOs to enter the microfinance sector and 
meet the sector's increasing demand. MISFA was recently transformed from an entity within a government program to an Afghan company with limited liability. It is now a non-shareholding company maintained by the Ministry of Finance (MoF) and governed by an independent Board of Directors. It gives MISFA greater autonomy in attracting new donors and maintaining those who continue to provide funding directly to the government to continue stimulating the country's microfinance sector's growth. Later MISFA established the Afghanistan Microfinance Association (AMA) in 2005 and is registered with the Ministry of Justice of Afghanistan in 2007 [5].

However, AMA was not very successful until 2010 due to scarce funds and was almost an inactive organization. Later support from the United States Agency for International Development (USAID)'s Financial Access for Investing in Afghanistan's Development (FAIDA) project and continuing MISFA support, AMA has backed as an organization that supports Afghanistan's development finance sector with lobbying and advocacy, business collaboration, and networking, capacity building, and information management. Moreover, the organization's main aim is to increase the sustainable development finance sector [6].

As per AMA quarterly report 2020, four MFIs, one Microfinance Bank (MFB) and three Community Savings Promoting Institutions (CSPIs) work in the country with a total gross loan portfolio of 8,181,361,864 AFN (Afghani). The total number of clients is 821,671, of which 220,924 are active borrowers. According to this report, $57 \%$ of the total active borrower are women, and 4,277 staff are working in these Microfinance Institutions. Moreover, the MFIs, MFB and CSPI cover 34 provinces with 208 branches in Afghanistan [7].

\section{LITERATURE REVIEW}

The microfinance concept was first developed in Bangladesh. Many countries have followed this framework to resolve the problems of financial exclusion and poverty. [8], declared that there had been a considerable growth of microfinance institutions in recent decades, which have played a significant role in growing income and employment opportunities for the vulnerable, especially women, in developing nations.

[9], described that microfinance has a significant relation with the customers' income. The author also noted that customers' income increased by 10 to 12 percent after borrowing loans in Indonesia, and around 30 percent positive impact in India and Bangladesh. In another research in India, microfinance programs slightly increased the customers' income [10]. [11], compared the income level of MFIs borrowers and non-browsers and concluded an increase in borrowers' income level. Similarly, in the study conducted in south-west Bangladesh, the opined that microfinance positively affected family income levels [12].

[13], researched the impact of microfinance activities on rural families and women of Bangladesh, the Philippines, and Uzbekistan. The study found that microfinance schemes positively affected women's position by making maximum cash in the family and having significant expenditure and saving engagement. Therefore, the study concluded that microfinance promotes the opportunity to achieve more revenue independently and play an active role in business decision-making and improve network skills, besides increasing asset acquisition. [14] explained that in order to start their business, microfinance organizations provide loans to women. The research also showed that microfinance loans had a significant effect on female entrepreneurs, and most women used the loan to start their businesses.

[15], determined that several countries, such as Nepal, Bangladesh, India, Vietnam, China, and the Philippines, have done an industry evaluation of MFIs. The author claimed that the support of MFIs, such as empowering women and independence, higher average family income, self-employment, and family members' employment, were recognized in these assessments. [16], described that microfinance, directly and indirectly, improves the customers' income and supports women in employment opportunities.

Microfinance offers lower-income individuals who need capital to set up or expand income-generating activities [17]. Microfinance emerged from the idea that micro-entrepreneurs and some needy borrowers may be 'bankable.' They can repay on schedule both the principal and interest and even make savings [18].

[19], researched a comparative study between the participant and non-participant microfinance in India. He stated that microfinance operation was influential in expanding economic activities in village areas. The authors also found that microfinance significantly impacted those who are participated in economic activities. Furthermore, the study also found that microfinance increased their family income, decreased income inequalities, and empowered women economically, socially, psychologically, and politically. 
Almost two decades of development growth in Afghanistan have shown that microfinance, savings, and other financial services are essential resources for poverty alleviation. Nevertheless, it is clear that access to financial services does alleviate poverty and, financial services should be made accessible to the poor in Afghanistan. Microfinance Institutions have a vital role in emerging entrepreneurship, household income generation. [20], noted that microfinance loans significantly affected small business enterprise's development, particularly female customers in Afghanistan. Moreover, evidence has shown that MISFA has a significant impact on entrepreneurial job opportunities and the development of existing and new businesses [21].

[22], stated that business activities such as farming, home-based tailoring services, livestock, carpet weaving, jewelry making, and shopkeeping could be carried out by all women's microfinance clients that increase their household assets in Afghanistan. The study also revealed that women entrepreneurs could enter into agreements with local store owners for items such as children's, women's, and men's clothes, crafts, quilts, pillows, rugs, and milk products.

[23], women entrepreneurs are a gradually increasing segment of the business population in Afghanistan, and a potential source of economic growth is women's innovative and entrepreneurial capacity. The number of women entrepreneurs remains low, despite this rising trend in women's participation in business.

[24], more than half of the Afghan people living under the national poverty line, Afghanistan, need to invest in private sectors to create job opportunities, support entrepreneurs and their business initiatives to expand and employment opportunities. Fortunately, Afghanistan is serious about progressing its investment environment, and the country is helping the challenges faced by entrepreneurs and investors.

\section{The objective of the study}

The study examines the impact of microfinance on entrepreneurs in Afghanistan. It compared the entrepreneurs' income before and after loaning from MFIs/MFB and examining their saving and employment generation.

\section{Hypothesis}

The Hypothesis: There is no significant impact of microfinance on entrepreneurs' income generation before and after availing loans from MFIs/MFB.

\section{METHODOLOGY}

The current research is a descriptive study that used secondary data from twenty-eight successful stories of men and women entrepreneurs financially supported by different microfinance institutions in Afghanistan. These stories were derived from published reports of MISFA, AMA, and their websites, journals, research articles, and other relevant websites.

To examine the impact of microfinance on entrepreneurs' income growth after availing loans from MFIs/MFB, the authors used the alternative Paired T-Test (Wilcoxon Sing Rank Test) as the extracted data was not normally distributed using IBM SPSS 25 version.

\section{IV.RESULTS AND DISCUSSION}

Table 1. Descriptive Statistics of Demographic

\begin{tabular}{lllc}
\hline \hline Variables & N/Valid Cases & Median & Percentage \% \\
\hline \hline Gender & 28 & 15 Female & 53.6 \\
Business Type & 28 & Tailoring & 14.3 \\
MFIs/MFB Name & 28 & Mutahid & 32.1 \\
Province & 28 & Balkh & 25 \\
Times of loan taken & 28 & 3 Times & 25 \\
\hline \hline
\end{tabular}

Source: AMA Reports

Table 1 shows that out of the 28 sample size, 15 ( $53.6 \%$ ) of the entrepreneurs are female, and $13(46.4 \%)$ are male, $14.3 \%$ having tailoring business, $32.1 \%$ of them have taken a loan from Mutahid, and $17.9 \%$ are have 
taken from FMFB, 14.3 from FINCA. 25. \% of the entrepreneurs having business in Balkh Province. Further, $25 \%$ of entrepreneurs have taken loans three times.

Table 2. Wilcoxon Signed Ranks Test (Ranks)

\begin{tabular}{|c|c|c|c|c|}
\hline & & $\mathbf{N}$ & $\begin{array}{l}\text { Mean } \\
\text { Ranks }\end{array}$ & Sum of Ranks \\
\hline \multirow{4}{*}{$\begin{array}{l}\text { Monthly Income Before Availing loan from } \\
\text { MFIs/MFB } \\
\text { Monthly Income After Availing loan from } \\
\text { MFIs/MFB }\end{array}$} & Negative Ranks & $0^{\mathrm{a}}$ & 2.00 & 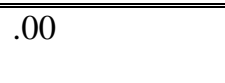 \\
\hline & Positive Ranks & $28^{\mathrm{b}}$ & 14.50 & 406.00 \\
\hline & Ties & $0^{\mathrm{c}}$ & & \\
\hline & Total & 28 & & \\
\hline
\end{tabular}

a. Monthly income after availing loan from MFIs/MFB < Monthly income before availing loan from MFIs/MFB

b. Monthly income after availing loan from MFIs/MFB > Monthly income before availing loan from MFIs/MFB

c. Monthly income after availing loan from MFIs/MFB = Monthly income before availing loan from MFIs/MFB

Table 3. Test Statistics

Monthly Income Before and After Availing Loan from MFIs/MFB

\begin{tabular}{lc}
\hline \hline $\mathrm{Z}$ & $-4.624^{\mathrm{b}}$ \\
Asymp. Sig. (2-tailed) & .000
\end{tabular}

d. Wilcoxon Signed Tanks Test

Source: MFIs/MFB Reports

e. Based on negative Ranks

As the $\mathrm{p}$-value calculated is 0.000 and $\mathrm{Z}$ value $=-4.624$ in a sense $\mathrm{p}$-value cal $=0.000<0.05$ (table value) from the Wilcoxon test, the null hypothesis has rejected the result indicated that microfinance has a positive impact on entrepreneurs income generation after availing loans from MFIs/MFB. (Table - 3).

Table 4. Descriptive Statistics of Income Level

\begin{tabular}{lcc}
\hline & $\begin{array}{c}\text { Monthly Income Before Availing Loan } \\
\text { from MFIs/MFB }\end{array}$ & $\begin{array}{c}\text { Monthly Income After Availing } \\
\text { Loan from MFIs/MFB }\end{array}$ \\
\hline \hline $\mathrm{N}$ & 28 & 28 \\
Median & $6,500.00$ & $42,500.00$ \\
Std. Deviation & 19679.778 & 63759.925 \\
\hline \hline
\end{tabular}

Source: Calculated from analysis

Microfinance customers' primary income source is small businesses such as bakery, beauty parlor, carpet weaving, embroidery, grocery shop, tailoring, and poultry. All the entrepreneurs accepted the positive effects of 
microfinance on their income (Table-2). Before using the loan, the MFIs/MFB customers' average monthly income was 6,500 AFN and increased to 42,500 AFN after receiving a loan from MFIs/MFB (Table - 4).

Table 5. Details of Selected Entrepreneurs Cases

\begin{tabular}{|c|c|c|c|c|c|c|c|c|c|}
\hline $\begin{array}{c}\text { Customer's } \\
\text { S.No }\end{array}$ & Age & Gender & $\begin{array}{c}\text { Times of } \\
\text { loan taken }\end{array}$ & Loan Amount & $\begin{array}{c}\text { MFIs/MFB } \\
\text { Name }\end{array}$ & Employment & Saving & Business Type & $\begin{array}{c}\text { Location } \\
\text { ( Provinces) }\end{array}$ \\
\hline 1 & 37 & Male & 3 & 310,000 & FINCA & & 90,000 & Grocery Shop & Kunduz \\
\hline 2 & 22 & Female & 4 & 190,000 & Mutahid & 5 & 5000 & Embroidery & Kabul \\
\hline 3 & 40 & Female & 4 & 650,000 & OXUS & 1 & 10,000 & Beauty Parlor & Kabul \\
\hline 4 & 30 & Male & & $1,900,000$ & FINCA & 4 & & Stone processing & Kabul \\
\hline 5 & 28 & Male & 3 & 530,000 & Mutahid & 3 & & Bakery & Herat \\
\hline 6 & 42 & Female & 4 & 600,000 & OXUS & 8 & 10,000 & Tailoring & Kabul \\
\hline 7 & 40 & Female & 4 & 160,000 & IIFC & 15 & 10,000 & $\begin{array}{l}\text { Producing wool } \\
\text { clothes }\end{array}$ & Balkh \\
\hline 8 & 65 & Male & 1 & 25,000 & HIHA & & & Chicken Shop & Samangan \\
\hline 9 & 39 & Female & 3 & 120,000 & FINCA & 20 & 5,000 & $\begin{array}{l}\text { Children's food at } \\
\text { home }\end{array}$ & Balkh \\
\hline 10 & 40 & Female & 4 & 250,000 & Mutahid & 5 & & Beauty Parlor & Kabul \\
\hline 11 & 53 & Male & 4 & 575,000 & FMFB & 1 & 3,000 & Grocery shop & Balkh \\
\hline 12 & 27 & Male & 4 & 250,000 & Mutahid & 5 & 1,5000 & Bakery & Balkh \\
\hline 13 & 46 & Female & 4 & 145,000 & FINCA & 6 & & Weaving carpets & Herat \\
\hline 14 & 40 & Female & 3 & 550,000 & FMFB & 2 & & Beauty Parlor & Herat \\
\hline 15 & 36 & Male & 1 & 15,000 & HIHA & 5 & & Poultry & Samangan \\
\hline 16 & 24 & Female & 1 & 35,000 & Mutahid & & & $\begin{array}{l}\text { Producing } \\
\text { women's dresses }\end{array}$ & Herat \\
\hline 17 & 38 & Male & 2 & 450,000 & IIFC & & & Photo Studio & Kunduz \\
\hline 18 & 30 & Female & 5 & 290,000 & FMFB & & 4,000 & Tailoring & Balkh \\
\hline 19 & 47 & Female & 4 & 200,000 & $\begin{array}{l}\text { IIFC \& } \\
\text { OXUS }\end{array}$ & & 15,000 & $\begin{array}{l}\text { Sewing dresses } \\
\text { and design }\end{array}$ & Balkh \\
\hline 20 & 32 & Female & 3 & $1,000,000$ & FMFB & 11 & 13,000 & Handicraft & Kabul \\
\hline 21 & 47 & Male & 6 & & FMFB & 6 & & $\begin{array}{l}\text { Cast iron tools } \\
\text { production }\end{array}$ & Kabul \\
\hline 22 & 25 & Female & 3 & 130,000 & OXUS & 8 & & Tailoring & Kabul \\
\hline 23 & 40 & Male & 2 & 190,000 & Mutahid & 3 & & Tailoring & Kabul \\
\hline 24 & 20 & Female & 3 & 210,000 & Mutahid & 3 & & Embroidery & Balkh \\
\hline 25 & 42 & Male & 4 & $1,400,000$ & Mutahid & 14 & 45,000 & Bakery & Herat \\
\hline 26 & 22 & Male & 2 & 750,000 & Mutahid & & & $\begin{array}{l}\text { Small grocery } \\
\text { shop }\end{array}$ & Herat \\
\hline 27 & 40 & Male & 1 & 50,000 & IIFC & 5 & & Restaurant & Kabul \\
\hline 28 & 40 & Female & 4 & 150,000 & OXUS & 5 & & $\begin{array}{l}\text { Silk carpet } \\
\text { weaver }\end{array}$ & Kabul \\
\hline
\end{tabular}

Source; AMA Reports

Table 5 shows that the average loan provided by MFIs/MFB to men and women entrepreneurs in Afghanistan is 412,037 AFN. They provide the loan depending upon the borrowers' requirements, and the lowest lending is 15,000 AFN and the highest being 1,900,000 AFN. On average, the men and women entrepreneurs generated six jobs after availing of the loan. The entrepreneurs provided 135 employment opportunities for others, and one borrower created a maximum of 20 jobs, the second one created 14 jobs and 11 jobs, and other entrepreneurs created less than ten jobs. However, there is no relationship between the employment generations and the amount 
of loan borrowed. The average savings of men and women entrepreneurs who borrowed loans is $12,273 \mathrm{AFN}$. One entrepreneur saved 45,000 AFN, and the lowest is 3,000 AFN. The savings made by the entrepreneurs are a positive sign of the men and women entrepreneurs due to the influence of MFIs/MFB. MFIs/MFB provided loans to the entrepreneurs in the five provinces, Kabul, Herat, Balkh, Kunduz, and Samangan of Afghanistan.

\section{CONCLUSION}

We evaluated the microfinance impact on entrepreneurs' income growth after loaning from MFIs/MFB in Afghanistan in the present case study. The study of 28 entrepreneurs cases of both men and females stories indicated that after borrowing from MFIs/MFB, these entrepreneurs either start their new micro or small businesses or developed their existing businesses. The authors accepted the alternative hypothesis because it determined that microfinance positively impacted their income level and increased significantly. The research also found that the saving level of these beneficiaries also profoundly improved. Consequently, the study's findings acknowledge the MFIs/MFB claims that these institutions' financial inclusion generates employment opportunities and improves entrepreneurs' earnings.

This study's limitation is that we only selected 28 cases available in AMA and MISFA reports. Further, research should be conducted on microfinance's effect on large-sample size based on primary data, leading to greater clarification on entrepreneurs' business activities in Afghanistan.

\section{References}

[1] Hailemichael, T., 2004. Technical Efficiency of Micro Finance Institutions in Ethiopia. Unpublished Thesis (M.A.), Addis Ababa University.

[2] Rao JN, Bavaiah MD. 2004. Impact of microfinance on household income-a study in Andhra Pradesh State in India. International Conference on Microfinance Development in Ethiopia, 21-23 January 2004, Awassa

[3] Yunus M (1999) The Grameen Bank. Scientific American 281(5): 114-119.

[4] Newman, A., Schwarz, S., \& Ahlstrom, D. (2017). Microfinance and entrepreneurship: An introduction. International Small Business Journal, 35(7), 787-792.

[5] Hussein, M. H. (2009). State of Microfinance in Afghanistan. Institute of Microfinance (InM).

[6] https://ama.org.af/archives/599, date: 20/02/2021

[7] Afghanistan Microfinance Association (AMA) (2020, December). Microview 30 a Quarterly update on Development Finance Outreach in Afghanistan. Retrieved from http://ama.org.af/wp-content/uploads/2021/02/MicroView-Report-31.pdf date: 20/02/2021

[8] Nawaz F. (2015). Microfinance, Financial Literacy, and Household Power Configuration in Rural Bangladesh: An Empirical Study on Some Credit Borrowers. Voluntas: International J. of Voluntary and Nonprofit Organizations. 26(4): 1100-1121. https://doi.org/10.1007/s11266-015-9585-z

[9] Hulme, D. and P. Mosley (eds.) (1996), Finance Against Poverty, Volume 1 and 2. London: Routledge.

[10] Chavan, P. and R. Ramakumar (2002), Microcredit and rural poverty: An analysis of empirical evidence. Economic and Political Weekly, Volume 37(10), March 9-15, pp. 955-965. http://www.jstor.org/stable/4411845

[11] Bebczuk R. N. \&Haimovich, F. 2007. MDGs and Microcredit: An empirical evaluation for Latin American Countries. Documentos de Trabajodel CEDLAS.

[12] Basu, S., Roy, A., \&Karmokar, S. (2020). Effectiveness of microfinance on household income generation strategy in the south-west region of Bangladesh. Asian J. Soc. Sci. Leg. Stud, 2(3), 56-62.

[13] Asian Development Bank (ADB). (2007). Effect of Microfinance Operations on Poor Rural Households and the Status of Women. Special Evaluation Study. Reference Number: SST: REG 2007-19, available at http://www.oecd.org/dataoecd/46/15/39503711.pdf

[14] Mahmood, S. (2011). Microfinance and women entrepreneurs in Pakistan, 3(3), 265-274. https://doi.org/10.1108/17566261111169340

[15] Bedson, J. (2009). Microfinance in Asia-Trends, Challenges, and Opportunities (1st ed.). Queensland, Australia: The Foundation for Development Cooperation.

[16] Choudhury, M. O. (2001). An impact assessment of micro-credit programs for rural women-experience of Bangladesh. Journal of the Institute of Bankers Bangladesh, 48, 1-47.

[17] Ojo.O (2009). Impact of Microfinance on Entrepreneurial Development: The Case of Nigeria, the International Conference on Economics and Administration, FAA, Bucharest, November 14, 2009. 
[18] Khan, K.A. and Rahman A. (2007). Why Do V.O. Members Drop Out? BRAC. Dhaka.

[19] Bansal, D. (2011). Impact of microfinance on poverty, employment, and women empowerment in rural Punjab. (Doctoral Dissertation). Department of Economics, Punjabi University, Patiala, India. available at: http://hdl.handle.net/10603/3031

[20] Echavez, C., Zand, S., \&Bagaporo, J. L. L. (2012). The Impact of Microfinance Programmes on Women's Lives: A Case Study in Balkh Province. Universitäts-und Landesbibliothek Sachsen-Anhalt.

[21] Hussein, M. H. (2009). State of Microfinance in Afghanistan. Institute of Microfinance (InM).

[22] Annual Report, 2006. PARWAZ.

[23] Microfinance Investment Support Facility for Afghanistan (MISFA) (2020, June). Quarterly newsletter. Retrieved from http://www.misfa.org.af/wp-data/uploads/2020/07/MISFA-e-Newsletter-June-2020.pdf. Date 16/02/2021

[24] Chaudhuri, S ( 2019, October 31) World Bank Blogs.worldbank.org./endpovertyinsouthasia/afghanistan-eases-doing-business 